\title{
ECONOMIC ASSESSMENT OF CONCENTRATION AND MONOPOLIZATION OF THE MARKET OF SPICES AND ESSENTIAL OIL PLANTS IN UKRAINE
}

\begin{abstract}
The article is devoted to the study of modern economic trends in the Ukrainian market of spicy and essential oil plants. The measurement of market concentration is carried out using concentration coefficients (indices), Lind, Herfindahl - Hirschman, relative concentration, entropy, variance of market shares of firms, Gini and Hall-Tideman. To study the degree of dominance of the largest participants in the Ukrainian market of essential oil and spice plants, the rigidity of its oligopoly core was determined. The results obtained allow us to conclude that when developing a strategy for the development of medicinal crop production in Ukraine, special attention should be paid to the need to create a competitive environment in this industry.
\end{abstract}

Keywords: production of spice plants, production of essential oil plants, market concentration, market monopolization, oligopoly core.

\section{INTRODUCTION}

Nowadays the development of production of medicinal plants is rapidly increasing. A large group of medicinal crops that are distinguished in the scientific literature and practice is medicinal oil-bearing plants containing essential oils. They are called mixtures of volatile aromatic substances that are formed in plants and have the ability to be distilled with water vapor. The name comes from the XVIII century, when nothing was known about the chemical composition of these substances. They were called essential oils because they are volatile, like ether, and oils - because they are fat, lighter than water and do not mix with it. Although the term is not quite accurate, it is still used in the world. Nowadays essential oils are already included in thousands of medicines and attract more and more attention as a powerful means of preventing any diseases. It is not coincidentally that the world production of essential oils are constantly increasing and has already reached 250 thousand tons per year. Currently, the fields of application of essential oils

\footnotetext{
${ }^{1}$ Tetiana Mirzoieva, PhD, Prof. I.N. Romanenka Department of Economy of Enterprise, National University of Life and Environmental Sciences of Ukraine; e-mail: mirzoeva2018@ukr.net (corresponding author). ORCID: 0000-0002-0034-6138.

2 Olga Tomashevska, PhD, Prof. I.N. Romanenka Department of Economy of Enterprise, National University of Life and Environmental Sciences of Ukraine; e-mail: tomashevska2011@ukr.net. ORCID: 0000-0002-2444-7259.
} 
are: 1) food industry (mainly as food flavorings); 2) distillery industry; 3) tobacco industry (for flavoring tobacco products, flavorings and essences are used, which may include essential oils of peppermint, coriander, valerian, vanilla etc.; 4) soap industry; 5) pharmaceuticals (as medical supplies and medicines);6) veterinary science; 7) perfumes and cosmetics (as components of perfumes and cosmetics); 8) aromatherapy; 9) household chemicals; 10) paint and varnish industry (as solvents); 11) production of rubber and plastics. The extremely wide use of essential oils obtained from essential oil plants is a strong argument in favor of further development of its production.

There is quiet a large group of medicinal plants that are produced in significant amount both in Ukraine and in the world called spicy crops. Their popularity is due to their value, primarily in cooking and the possibility of using them for medicinal purposes. There is even a version that humanity began to use spicy-aromatic plants to improve the taste of food earlier than salt (Melnychuk, 2016). The combination of spicy medicinal plants is also quite large. In particular, these are such crops as anise, basil, mustard, oregano, marjoram, coriander, cumin, fennel, parsnip, lovage etc.

The demand for medicinal herbs in general and for spices and essential oils, in particular, has been growing rapidly in recent decades around the world and in Ukraine. This is largely because the trend towards a healthy lifestyle is spreading more and more. Consequently, essential oil and spice medicinal herbs and products of their processing, due to their inherent healing properties, are in increasing demand. Agrarians' interest in the production of medicinal plants is also increasing significantly in the context of modern times. Firstly, the world is experiencing climate changes. Thus, in the southern regions of Ukraine, because of global warming, it is becoming more difficult to grow traditional agricultural crops - sunflower, corn, wheat and so on. Farmers face the need to re-focus on the production of drought-resistant and stress-resistant crops. That is why, there is increasing interest in the production of medicinal plants, a significant part of which can easily tolerate drought. Secondly, in Ukraine, because of intensive agricultural production in the last twenty years, as well as in the whole world, the soil condition has significantly deteriorated. As a result, the yield of traditional agricultural crops is reducing. World grain prices also tend to decline. For Ukraine, which is one of the leaders in grain production on the world stage, these facts are extremely negative. Consequently, Ukrainian farmers are increasingly considering the possibility of diversifying production and entering new market niches focused on exports (Mirzoieva, 2019). Thirdly, interest in the production of essential oil and spice medicinal herbs is growing, primarily in the sphere of Ukrainian small and medium-sized agricultural businesses. Its representatives often consider this direction as an opportunity to take a place in a highly profitable niche. The relevance of the research topic is due to the need to increase the production of essential oil and spice crops in order to develop a high-tech and export-oriented industry in Ukraine.

\section{LITERATURE REVIEW}

Many leading scientists have considered various aspects of the development of production of spices and essential oils in their research. Carrubba A. and Catalano C. (2009) consider the production of essential oil crops as an opportunity to obtain a strategic product, essential oils, for many industries. Scientists note that the value of essential oil plants is that: 1) they are suitable for various purposes; 2) even small producers in rural area can process them; 3) in many cases, they can be grown using environmentally 
friendly or organic methods. The last argument provides significant economic advantages to etheric oil crops and makes it possible to use them in the segment of «natural» products (Carrubba, Catalano, 2009).

Derek Byerlee, Walter P. Falcon, and Rosamond L. Naylor (2017) investigate the versatility of essential oil medicinal plants in the context of growing tropical species for food, animal feed, and fuel production (Byerlee, Falcon, Naylor, 2017).

In a research, that was presented to the scientific community in 2015 regarding the production of essential oil crops and essential oils in South Africa, this segment is considered as an opportunity for development. In a study that was presented to the scientific community in 2015 on the production of essential oils and essential oils in South Africa, this segment is considered as an opportunity for the development of agricultural enterprises, as a means of livelihood in rural areas, as an example of partnership between poor rural communities (Rural enterprise partnerships. the case of essential amathole, 2015).

In 2019, the project Initiative of the agricultural productivity and commercialization (IAPAC) based on the example of Nepal, developed by the Austrian Development Agency with the support of the European Union, was published. The project contains suggestions and recommendations on income generation opportunities for rural families by the cultivation of essential oil and spice crops on unproductive land or within woodlands. The project experience shows that medicinal crops can be an important source of income and employment for the population. The main stress is on the fact that small farmers and landless farms can develop by producing medicinal plants (Essential Oil Crop Production in Private and Community Forest Land, 2019). Scientists Ramu Govindasamy, Surendran Arumugam, and James E. Simon (2013) study the overall global market for essential oils and the plants that produce them and provide UN statistics, according to which the main consumers of essential oils are the United States (40\%), Western Europe $(30 \%)$ and Japan (7\%). Moreover, the trade volumes in essential oils and related products in the world is increasing by about $10 \%$ annually (Govindasamy, Arumugam, Simon, 2013).

In the modern scientific world, many publications are also devoted to the study of the economy of production of spice crops, which are the main source of spices. Thus, Arghya Mani and Arpan Kabiraj (2019) highlight the importance and necessity of spice crops and analyze the export of spices and spice-based products. And they focus on the fact that, first of all, these are products with added value (Mani, Kabiraj, 2019).

It is worth mentioning that in the development of spice production, it is advisable to focus on Indian producers, since in the modern world, India is the largest producer, consumer and exporter of spices.

In particular, this country produces about 75 of the 109 varieties of spice crops listed by the International Organization for Standardization (ISO) and accounts for half of the world's spice trade. Demand for primary and secondary spice crops is growing rapidly in both India and the world (2020) (Indian Spices Industry, 2020). The global spice and seasoning market is predicted to grow at an annual rate of 5\%. According to the latest researches, spices are used in the process of production of food and cosmetic products, pharmaceutical products (Global Spices and Seasonings Industry, 2019).

In general, the authors-researchers of the production of spices and essential oils agree that this segment contributes to the development of small and medium businesses in the agricultural area, employment of rural populations and the creation of value-added 
products. In Ukraine, these goals have not been fully achieved yet. Therefore, the author explores the possibility of solving the scientific and practical problem of forming an effective market for spices and essential oils in the framework of the strategic development of the medicinal plant industry in Ukraine. The purpose of this study is to assess the economic level of concentration and monopolization of markets for spice and essential oil crops in Ukraine.

\section{METHODOLOGY OF RESEARCH}

According to the author, an economic assessment of the level of concentration and monopolization of the medicinal plant market in Ukraine and research of trends in this market can be used as a methodological basis for forming a strategy for the development of medicinal plant production. In order to determine the number of enterprises that create a business environment in the field of medicinal plants and identify their impact on the development of the industry, a profound quantitative analysis was made.

In particular, the concentration of a particular market is measured using the following coefficients (indices) (Pervakov, 2009): concentration, Lind, Hergindahl-Hirschman, relative concentration, entropy, variance of market shares of firms, Gini, Hall-Tademanor, Rosenbluth etc.

In modern conditions, many enterprises operate at many markets, including quite a few large companies. But not all large enterprises have the same impact on the market. To study the degree of dominance of the largest participants in the Ukrainian market of essential oils and spices, it will be necessary to determine the rigidity of its oligopoly core, because only if it is present, there is a possibility of anti-competitive concerted actions. To do this, use the Lind index, which is an effective tool for determining the «border» of an oligopoly and it is calculated using the formula:

$$
\mathrm{L}=\frac{1}{\mathrm{~K}(\mathrm{~K}-1)} \mathrm{x} \sum_{\mathrm{i}=1}^{\mathrm{k}} \mathrm{Q}_{\mathrm{i}}
$$

Where $k$ - the number of significant business entities; $Q i$ - the ratio between the average market shares and business entities and $k+l$ business entities; $i$ - the number of leading business entities among $k$ significant business entities (Valitov, 2006).

$$
Q_{i}=\frac{S_{i}}{i}+\left(\frac{S_{k}-S_{i}}{K-i}\right)
$$

where $S_{i}$ - total market share of $i$ economic entities; $S_{k}$ - market share of $k$ significant entities. The Lind index is calculated in stages: firstly, for the two largest enterprises, then for the three, andso on untill getting a violation of the continuity of reducing the indicator $\mathrm{L}$, that is, until the result $L L k k>-1$ appears. Violation of continuity states, that the last added to the computation enterprise, has significantly smaller market share than any of the previous (Okrepkyi, Myhal, 2016). Large significance in further analysis is the investigation of dispersion of oligopoly core. Because even in a highly concentrated market, there can be an active competitiondue to the uniform distribution of particles and the ratio of the sizes of individual subjects, thatincluded in it. In order to be able to carry out research on the dispersionof the oligopoly core, it is necessary to calculate the share of each of the leading enterprises in the oligopoly core in the Ukrainian market of essential oils and spices. The results obtained will allow us to determine the uniformity of the 
distribution of market shares between competing enterprises. This, in turn, will make it possible to assess the risks of collective monopolization, that is, the attainment of a dominant position in the market by leading enterprises throughcoordinated behavior.To do this, use a generalized the Herfindahl-Hirschman Index (HHI), that is calculated using the formula:

$$
H H I=\sum_{i=1}^{k} S_{i}^{2}
$$

To determine the degree of market concentration the Hall-Tideman index or Rosenbluth index (IR)can be used. It demonstrates the number of competitors, the share of each of them in the total sales volume of products, and the ranks of these particles. It is calculated based on comparing the ranks of enterprises in a particular market:

$$
I_{R}=\frac{1}{2 \sum_{i=1}^{n} i \cdot S_{i}-1}
$$

where $i$ - rank of the company's share from maximum to minimum (Zaitseva, 2011). The maximum value of the Hall-Tideman index is one (under monopoly conditions). The minimum value is $1 / N$, where $N$ - is the number of enterprises in the sector. The advantage of the Hall-Tideman index is the ability to rank businesses by their degree of significance, which contributes to a deeper analysis of a particular industry. The disadvantage is that this index cannot be calculated in full at a certain time, it must be considered in dynamics (Horniak, Filipovych, 2012).

In order to assess the possible market power of enterprises, taking into account the inequality of their size, the indicator of market share dispersion is used.This indicator reflects the degree of uneven distribution of enterprise shares in a particular market and is based on the formula:

$$
\sigma^{2}=\frac{1}{n} \sum_{i=1}^{n}\left(S_{i}-\bar{S}^{2}\right.
$$

where $\sigma$ - average square deviation of market shares of enterprises; $\mathrm{Si}-$ share of $i$ enterprise in the market; $S$ - average share of the enterprise in market; $n$ - number of enterprises (Volkov, Horoshkova 2011).

In addition, the coefficient of variation is also used to assess the uniformity of distribution of production and sales volumes between market-leading enterprises (Pietieshova, 2011). It is calculated using the formula:

$$
V=\sigma: \bar{S}
$$

The greater unevenness of the distribution of shares of enterprises corresponds to the higher values of the indicators of variance and variation.

Pre-calculated indices will allow you to measure concentration directly and only indirectly competition in the market. Concentration means that there is a certain order in the market that is set by large enterprises. While competition is characterized by «promiscuous» movement of the enterprises and the market entropy. Due to this, entropy indicators can be used to measure the degree of competition directly. In other words, the entropy coefficient is used to assess the degree of disorderliness of a particular market. It 
is the sum of the sales shares of enterprises that operate in the market, weighted by the natural logarithm of the inverse value:

$$
E=\sum_{i=1}^{n} S_{i} \ln \frac{1}{S_{i}}
$$

The value of the entropy index ranges from 0 to 1 . The higher this indicator, the higher the level of competition in the market. Along with this coefficient, the relative entropy index is calculated (E0):

$$
E_{0}=\frac{E}{\ln (n)}
$$

A mathematical indicator of the uneven distribution of a particular market is the Gini coefficient (index) (G). It allows to determine how evenly a particular variable is distributed among market participants. The value of the Gini coefficient varies in the range from zero to one. In the case that the coefficient is equal to zero, we can state the condition of absolute equality, and if the one - are absolute inequality.

The higher the coefficient value, i.e. the closer it approaches one, the greater the differentiation in the market distribution between individual producer enterprises. The calculation of this index for a set of enterprises that are part of the oligopoly core of the market of essential oil and spice crops should be carried out using the formula:

$$
G=\frac{1}{n}\left(n+1-2\left(\frac{\sum_{i=1}^{n}(n+1-i) y_{i}}{\sum_{i=1}^{n} y_{i}}\right)\right)
$$

where $n$-the number of enterprises in the aggregate; $\mathrm{y}_{\mathrm{i}}$ is the market share of the $i$ enterprise.

\section{RESULTS}

The direct research of the current state of medicinal plants production in Ukraine is complicated by the fact that statistical information is extremely insufficient. Centralized analysis of the current state of procurement and cultivation of medicinal plants in Ukraine is practically absent, a number of indicators regarding the functioning of the industry is simply not tracked. In addition, it is worth mentioning, that, since medicinal crop production is not distinguised as a separate industry, everything related to medicinal plants in the statistical collections of the State statistics service is displayed in the section «Technical crops». Secondly, only since 2016, the State statistics service of Ukraine began to reflect data in the context of individual medicinal crops, before that the distinction went to such groups as «medicinal plants», «etheric-oilseeds» and «coriander». Accordingly, information was provided in statistical yearbooks for these three groups. We assume that the selection of coriander in a separate line is due to its value as an essential oil culture.Thus, experts note that the volume of production of coriander essential oil is inferior to almost all the most famous crops, except, perhaps, roses and lavender. Its fruits contain up to $20-25 \%$ of fatty oil and $1,5-3 \%$ of essential oil. In addition, the composition of coriander essential oil is stable and almost does not differ depending on the variety or growing area (Koriandr: likarski ta korysni vlastyvosti, http). Since 2016, statistical 
information in Ukraine has been enriched with information about the production of «spice crops» and medicinal plants in the context of individual crops, not just coriander.

A characteristic feature of the development of production of essential oil and spice crops in Ukraine is that the industrial production of a number of crops is gradually scaling up. These are crops that until recently were not grown on the territory of the country in general or in small amounts, or those that were not grown due to the fact that they needed other climatic conditions. But due to global warming, it is now possible to grow them in Ukraine.

Analysis of sales of spice crops by enterprises in Ukraine in 2018 showed that $66.2 \%$ of Ukrainian spices were sold by two enterprises (table 1). This fact indicates the existence of monopolistic trends in the production of spice crops in Ukraine.

Table 1 . Spice sales by enterprise (2018)

\begin{tabular}{|c|c|c|}
\hline $\begin{array}{l}\text { Number of } \\
\text { enterprise }\end{array}$ & Volume of products sold, centner & Share in total product sales, $\%$ \\
\hline 1 & 6219 & 33,65 \\
\hline 2 & 6014 & 32,54 \\
\hline 3 & 1024 & 5,54 \\
\hline 4 & 842 & 4,56 \\
\hline 5 & 787 & 4,26 \\
\hline 6 & 566 & 3,06 \\
\hline 7 & 426 & 2,31 \\
\hline 8 & 390 & 2,11 \\
\hline 9 & 385 & 2,08 \\
\hline 10 & 291 & 1,57 \\
\hline 11 & 277 & 1,50 \\
\hline 12 & 275 & 1,49 \\
\hline 13 & 240 & 1,30 \\
\hline 14 & 233 & 1,26 \\
\hline 15 & 225 & 1,22 \\
\hline 16 & 100 & 0,54 \\
\hline 17 & 95 & 0,51 \\
\hline 18 & 75 & 0,41 \\
\hline 19 & 17 & 0,09 \\
\hline
\end{tabular}

Source: Official site of the State Statistics Service of Ukraine (2019) (http://www. ukrstat.gov.ua) authors' own depiction.

In table 2 the results of the study of the rigidity of the oligopoly core in the segment of spicy medicinal plants using the Lind index are presented. 
Table 2. Calculation of the Linda index for the spice market in 2018

\begin{tabular}{|c|c|c|c|c|c|c|c|c|}
\hline $\boldsymbol{k}$ & $\boldsymbol{Q 1}$ & $\mathbf{Q 2}$ & $\mathbf{Q 3}$ & $\boldsymbol{Q 4}$ & $\mathbf{Q 5}$ & $\boldsymbol{Q 6}$ & $\boldsymbol{Q 7}$ & $\boldsymbol{L}_{\boldsymbol{k}}$ \\
\hline 2 & 1,034 & & & & & & & 0,517 \\
\hline 3 & 1,767 & 5,973 & & & & & & 1,290 \\
\hline 4 & 2,368 & 6,556 & 5,24829 & & & & & 1,181 \\
\hline 5 & 2,870 & 6,917 & 5,425 & 4,47877 & & & & 0,985 \\
\hline 6 & 3,368 & 7,600 & 6,040 & 5,210 & 5,26001 & & & 0,916 \\
\hline 7 & 3,863 & 8,390 & 6,744 & 5,944 & 6,002 & 6,04533 & & 0,881 \\
\hline 8 & 4,332 & 9,095 & 7,338 & 6,500 & 6,463 & 6,312 & 5,959 & 0,821 \\
\hline
\end{tabular}

According to the performed calculations, the breach of continuity has occurred atk=3 $\left(\mathrm{L}_{3}>\mathrm{L}_{2}\right)$, therefore, the oligopoly is created by the first in their market share of farms properties, which provide $66,2 \%$ of the sold products. The character of such an oligopoly is defined rather as «rigid».This is the evidence that two companies dictate the trends in the segment of production of spicy medicinal crops, all other manufacturers are largely dependent on this.

In order to carry out the research on the dispersion of the oligopoly core, the share of each of the leading enterprises within the oligopoly core in the Ukrainian segment of medicinal herbs was calculated (table 3 ).

Table 3. Market share of enterprises that are part of the oligopoly core

\begin{tabular}{|c|c|c|}
\hline $\begin{array}{c}\text { Number of } \\
\text { enterprise }\end{array}$ & Market share, $\%$ & Share in the oligopoly core, $\%$ \\
\hline 1 & 34,61 & 50,84 \\
\hline 2 & 33,47 & 49,16 \\
\hline
\end{tabular}

The calculation of the shares of enterprises that belong to the oligopoly core allows us to emphasize the importance of the largest business entity in the total combination. The results show that the two leading enterprises in the spice market in Ukraine have almost the same weight.

Table 4. Spice market concentration indices in Ukraine in 2018

\begin{tabular}{|l|c|}
\hline \multicolumn{1}{|c|}{ Indicator } & Value \\
\hline Herfindahl - Hirschman index & 5001 \\
\hline Hall-Tideman index & 0,504 \\
\hline The dispersion of market shares & 0,7 \\
\hline The coefficient of entropy & 0,734 \\
\hline The coefficient of relative entropy & 1,058 \\
\hline
\end{tabular}

The actual Herfindahl-Hirschman index indicates that there is a limited oligopoly in the Ukrainian spice market. The Hall-Tidman Index (Rosenbluth), which helps to take into account the size ratio of enterprises, is quite low (the minimum level for the surveyed enterprise population is 0.143 ), which indicates the limited market power of economic entities. The high value of the variance of market shares is caused by a significant gap between the market share of the largest manufacturer and other competitors. The same 
circumstance explains the level of entropy coefficients and relative entropy, which measure the uneven distribution of market shares between economic entities. The lower the value of these indicators, the greater the ability of sellers to influence the market price.

The Lorentz curve shows the degree of uneven distribution of a certain market among the main manufacturing enterprises more clearly (fig. 1). As you can see from the figure, the actual Lorentz curve deviates from the line of uniform distribution. This means that there is an inherent difference in market shares for the studied set of enterprises.

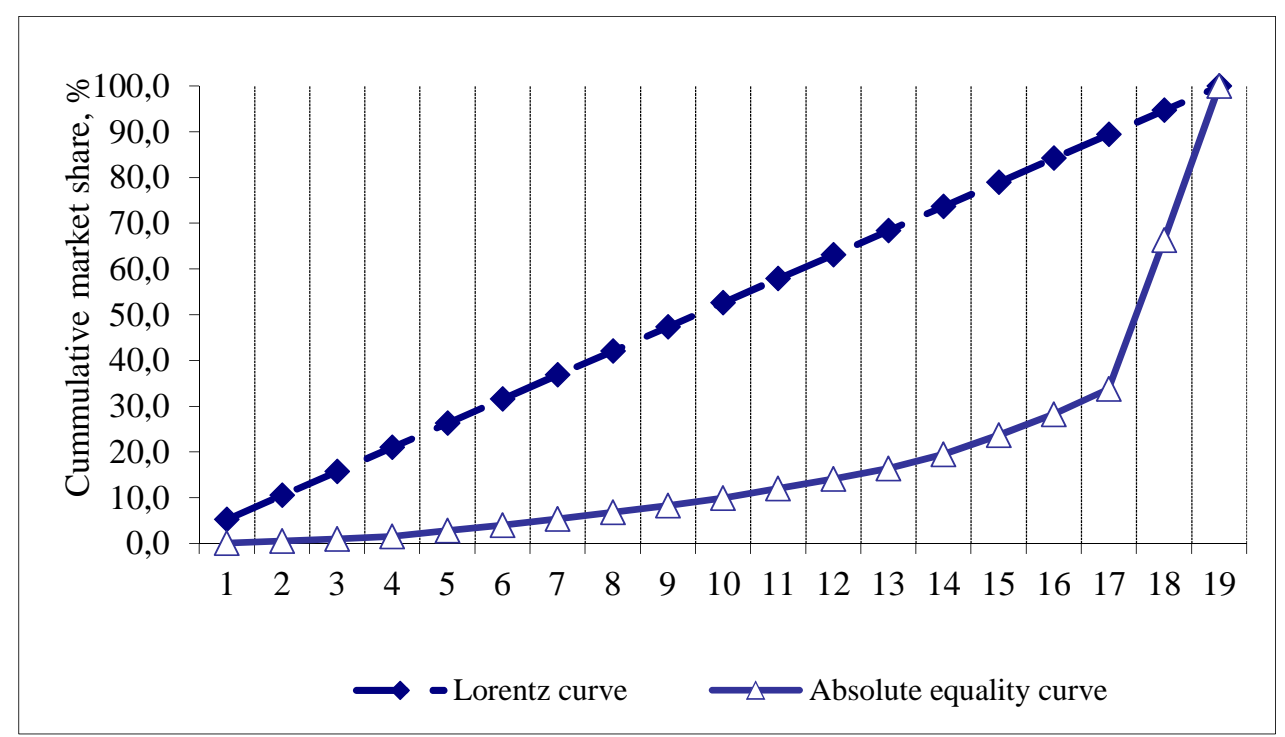

Fig. 1. Lorentz curve of the spice market in Ukraine

Source: own study.

The obtained value of the Gini index $(0,508379)$ confirms the presence of unevenness in the distribution of the studied market among its participants, which increases the probability of a tendency to reduce competition and increase the monopolization of the market of spice crops.

The analysis of the sale of essential oil crops by enterprises in Ukraine in 2018 showed that 50,3\% of Ukrainian spices were sold by two enterprises (table 5). This fact indicates that there are monopolistic trends in the production of essential oil crops, as well as in the production of spices in Ukraine, although to a lesser extent. Although it is a positive fact that according to official statistics the number of producers of essential oil crops in Ukraine is twice as large as the number of producers of spices. In addition, most of these enterprises can be attributed to small businesses, which can also be considered as a positive phenomenon, since small agricultural firms are the basis of agribusiness around the world (Herasymchuk, 2011). 
Table 5. Implementation of essential oil crops in terms of companies (2018)

\begin{tabular}{|c|c|c|}
\hline $\begin{array}{c}\text { Number of } \\
\text { enterprise }\end{array}$ & $\begin{array}{c}\text { Volume of } \\
\text { products sold, } \\
\text { centner }\end{array}$ & $\begin{array}{c}\text { Share in total } \\
\text { product sales, } \\
\text { \% }\end{array}$ \\
\hline 1 & 20745 & 30,3 \\
\hline 2 & 13705 & 20,0 \\
\hline 3 & 5750 & 8,4 \\
\hline 4 & 3960 & 5,8 \\
\hline 5 & 3510 & 5,1 \\
\hline 6 & 2458 & 3,6 \\
\hline 7 & 2379 & 3,5 \\
\hline 8 & 1874 & 2,7 \\
\hline 9 & 1716 & 2,5 \\
\hline 10 & 1570 & 2,3 \\
\hline 11 & 1186 & 1,73 \\
\hline 12 & 1121 & 1,64 \\
\hline 13 & 1049 & 1,53 \\
\hline 14 & 889 & 1,30 \\
\hline 15 & 841 & 1,23 \\
\hline 16 & 631 & 0,92 \\
\hline 17 & 621 & 0,91 \\
\hline 18 & 500 & 0,73 \\
\hline 19 & 478 & 0,70 \\
\hline & & \\
\hline
\end{tabular}

\begin{tabular}{|c|c|c|}
\hline $\begin{array}{c}\text { Number of } \\
\text { enterprise }\end{array}$ & $\begin{array}{c}\text { Volume of } \\
\text { products sold, } \\
\text { centner }\end{array}$ & $\begin{array}{c}\text { Share in } \\
\text { total product } \\
\text { sales, \% }\end{array}$ \\
\hline 20 & 398 & 0,58 \\
\hline 21 & 323 & 0,47 \\
\hline 22 & 305 & 0,45 \\
\hline 23 & 294 & 0,43 \\
\hline 24 & 287 & 0,42 \\
\hline 25 & 230 & 0,34 \\
\hline 26 & 219 & 0,32 \\
\hline 27 & 209 & 0,31 \\
\hline 28 & 164 & 0,24 \\
\hline 29 & 163 & 0,24 \\
\hline 30 & 147 & 0,21 \\
\hline 31 & 128 & 0,19 \\
\hline 32 & 118 & 0,17 \\
\hline 33 & 104 & 0,15 \\
\hline 34 & 95 & 0,14 \\
\hline 35 & 90 & 0,13 \\
\hline 36 & 50 & 0,07 \\
\hline 37 & 33 & 0,05 \\
\hline 38 & 33 & 0,05 \\
\hline & & \\
\hline
\end{tabular}

Source: Official site of the State Statistics Service of Ukraine (2019) (http://www. ukrstat.gov.ua') authors' own depiction.

The calculation of the Lind index for the market of essential oil crops in 2018 shows that the continuity violation occurred at $\mathrm{k}=7$ (L7 > L6), therefore, the oligopoly is created by the six first in their market share of farms that provide $73.3 \%$ of the sold products.

Table 6. Calculation of the Lind index for the market of essential oil crops in 2018

\begin{tabular}{|c|c|c|c|c|c|c|c|c|c|}
\hline $\boldsymbol{k}$ & $\boldsymbol{Q 1}$ & $\boldsymbol{Q 2}$ & $\boldsymbol{Q 3}$ & $\boldsymbol{Q 4}$ & $\mathbf{Q 5}$ & $\mathbf{Q 6}$ & $\boldsymbol{Q 7}$ & $\boldsymbol{Q 8}$ & $\boldsymbol{L} \boldsymbol{k}$ \\
\hline 2 & 1,514 & & & & & & & & 0,957 \\
\hline 3 & 2,133 & 2,996 & & & & & & & 0,855 \\
\hline 4 & 2,658 & 3,548 & 3,384 & & & & & & 0,799 \\
\hline 5 & 3,082 & 3,909 & 3,588 & 3,145 & & & & & 0,686 \\
\hline 6 & 3,530 & 4,395 & 4,049 & 3,700 & 3,8788 & & & & 0,652 \\
\hline 7 & 3,919 & 4,770 & 4,355 & 3,968 & 3,942 & 3,512 & & & 0,683 \\
\hline 8 & 4,317 & 5,185 & 4,725 & 4,321 & 4,262 & 3,929 & 4,146 & & 0,552 \\
\hline 9 & 4,695 & 5,570 & 5,058 & 4,624 & 4,525 & 4,199 & 4,328 & 4,086 & 0,515 \\
\hline
\end{tabular}


The calculation of the shares of enterprises that are part of the oligopoly core of the market of essential oil crops in Ukraine confirmed the preliminary calculations and showed that a significant impact on its development is carried out by two major enterprises, as well as 4 other manufacturers, whose importance in the market can be considered as quite significant.

Table 7. Market share of enterprises included in the oligopoly core

\begin{tabular}{|c|c|c|}
\hline Number of enterprise & Market share, $\%$ & Share in the oligopoly core, $\%$ \\
\hline 1 & 30,3 & 41,4 \\
\hline 2 & 20,0 & 27,3 \\
\hline 3 & 8,4 & 11,5 \\
\hline 4 & 5,8 & 7,9 \\
\hline 5 & 5,1 & 7,0 \\
\hline 6 & 3,6 & 4,9 \\
\hline
\end{tabular}

The fact that, according to our calculations, the actual Herfindahl-Hirschman index has, indicates that a limited oligopoly has been established in the Ukrainian market of essential oil crops. The Hall-Tidman Index (Rosenbluth), which takes into account the ratio of the size of enterprises, has a relatively low value (the minimum level for the surveyed enterprise population is 0.143), which indicates the limited market power of economic entities. The high value of market share variance is explained by a significant gap between a share on market of the largest manufacturer (enterprise 1 has no name) and other competitors. This circumstance also explains the level of entropy coefficients and relative entropy, which measure the uneven distribution of market shares between economic entities. The lower the value of these indexes, the greater the ability of sellers to influence the market price.

Table 8.Indices of concentration of the market of essential oil crops in Ukraine in 2018

\begin{tabular}{|l|c|}
\hline \multicolumn{1}{|c|}{ Index } & Value \\
\hline Herfindahl - Hirschman index & 2727 \\
\hline Hall-Tideman index & 0,283 \\
\hline The dispersion of market shares & 187,9 \\
\hline The coefficient of entropy & 1,329 \\
\hline The coefficient of relative entropy & 0,742 \\
\hline
\end{tabular}

As you can see from the figure, the actual Lorentz curve deviates from the line of uniform distribution. This means that there is an inherent difference in market shares for the studied set of enterprises. 


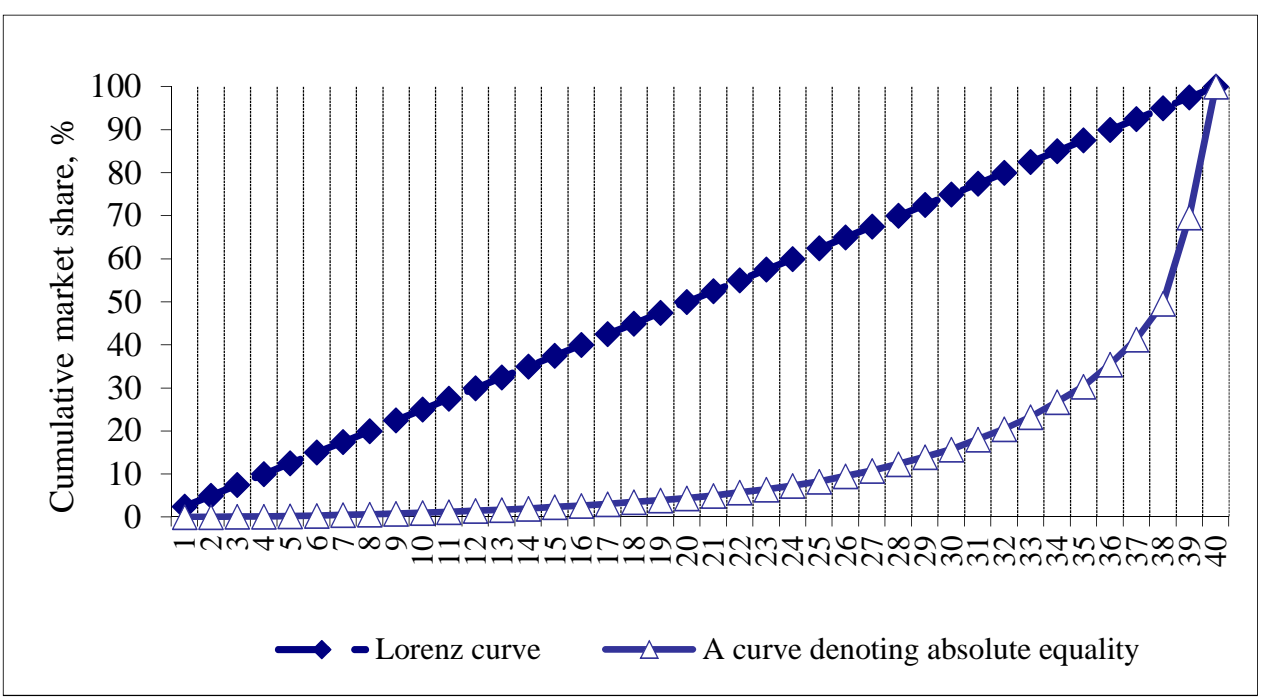

Fig. 2. Lorentz curve of the market of essential oil crops in Ukraine

Source: own study.

The obtained value of the Gini index (0.411646) confirms the presence of unevenness in the distribution of the studied market among its participants, which increases the probability of a trend to reduce competition and increase market monopolization.

\section{CONCLUSIONS}

Thus, the conductedassessment of concentration and monopolization of the markets of essential oil and spice crops in Ukraine indicates the actual absence of competition in these segments of the Ukrainian economy, the presence of a high-concentrated market and monopolistic trends. The market is actually created by 2-6 dominant firms, all the others play a quite minor role-both in terms of production volume formation and in terms of product price formation. A comparison of the markets showed that the spice market is more concentrated than the market of essential oils. In general, the presence of dominant firms within a certain market, as evidenced by world experience and the development of the world economy, does not contribute to the effective development of a particular industry. Therefore, for Ukraine, the issue of developing the production of essential oils and spices in particular and creating a strategy for the development of the industry of medicinal plants in general is extremely urgent. Activities in this direction will contribute to the expansion of areas for essential oils, spices and medicinal crops, the creation of a full-fledged processing subcomplex, which can include raw material processing plants, enterprises of the perfume and pharmaceutical industries, storage facilities and a sales system. With proper approach, further development of its own production of essential oil products and spices and medicinal plants raw materials can become one of the aspects of economic development of the country. At the same time, it should be noted that due to a complex of organizational, economic and technological problems, the dynamic development of the production of essential oils, spices and medicinal crops in Ukraine in general is quite problematic and requires thorough further research. 


\section{REFERENCES}

Arghya, M., Arpan, K. (2019). Export potential of spices and its value added products. Access on the internet: https://www.researchgate.net/publication/334771417_Export_potential_ of_spices_and_its_value_add.

Carrubba A., Catalano C. (2009). Essential Oil Crops for Sustainable Agriculture - A Review. Access on the internet: https://www.research gate.net/publication/226188481_ Essential_Oil_Crops_for_Sustainable_Agriculture_-_A_Review.

Derek, B., Walter P.F., Rosamond L.N. (2017). The Tropical Oil Crop Revolution: Food, Feed, Fuel, and Forests Oxford Universety Press. Access on the internet: https://books. google.com.ua/books?id=mwc1DQAAQBAJ\&pg=PT162\&lpg=PT162\&dq=The+dynamics+of +the+production+of+essential+oil+crops \&source $=$ bl\&ots $=$ hn0eKm1 v45\&sig $=$ ACfU3U3sxhd MM7YXiPn5WjkOwyQ3xFx_Zg\&hl=ru\&sa=X\&ved=2ahUKEwiYxJK67JDoAhUQposKHU pDBDM4ChDoATAEegQIChAB\#v=onepage $\& \mathrm{q}=$ The $\% 20$ dynamics $\% 20$ of $\% 20$ the $\% 20$ product ion $\% 20$ of $\% 20$ essential\%20oil\%20crops \&f =false.

Essential Oil Crop Productionin Privateand Community Forest Land (2019). Access on the internet: http://adranepal.org/wp-content/uploads/2018/09/1.-Essential-oil-crops-in-community-and-private-land.pdf.

Herasymchuk N.A. (2011). Konkurentospromozhnist ahrarnoho sektoru Ukrainy v umovakh svitovoi prodovolchoi kryzy. „Ekonomika. Upravlinnia. Innovatsii”, Vol. 2. Access on the internet: http://nbuv.gov.ua/UJRN/eui_2011_2_10.

Global Spices and Seasonings Industry (2019). Access on the internet: https://www. marketwatch.com/press-release/global-spices-and-seasonings-industry-2019-01-08.

Horniak V.O., Filipovych V.V. (2012). Teoretychni pidkhody do vymiriuvannia rivnia kontsentratsii ta monopolizatsii na suchasnykh rynkakh. Visnyk ONU imeni I.I. Mechnykova, Vol 1 (16).

Indian Spices Industry (2020). Access on the internet: https://www.mbarendezvous.com/ general-awareness/indian-spices-industry/ 2020.

Koriandr: likarski ta korysni vlastyvosti. Access on the internet: http://likarski-roslini. net.ua/koriandr-likarski-ta-korisni-vlastivosti/

Melnychuk O. (2016). Novi priano-aromatychni kultury ta yikh vykorystannia. Access on the internet: https://kraskor.in.ua/kkgr/2016/06/26/novi-pryano-aromatychni-kultury-ta-yih-

vykorystannya/

Mirzoieva T.V. (2019). Tendentsii koniunktury rynku likarskykh roslyn v Ukraini ta sviti. Zbirnyk naukovykh prats NUK, Vol. 4.

Official site of the State Statistics Service of Ukraine. Access on the internet: http://www.ukrstat.gov.ua

Okrepkyi R.B., Myhal O.F. (2016). Metodychni aspekty vykorystannia kilkisnykh indykatoriv kontsentratsii tovarnoho rynku ta stupenia yoho monopolizatsii. „Ukrainian Journal of Applied Economics", Vol. 1 (4/2016).

Pervakov O.S. (2009). Analiz mozhlyvostei zastosuvannia pokaznykiv rynkovoho dominuvannia dlia otsinky zahrozy ekonomichnii systemi. „Nauka y ekonomika”, Vol. 4(16).

Pietieshova T.A. (2011). Diahonostychni pidkhody do vyznachennia rivnia intensyvnosti konkurentsii na haluzevomu rynku. „Marketynh i menedzhment innovatsii”, Vol. 4.

Ramu, Surendran, James (2013). An assessment of the essential oil and aromatic plant industry with a focus on Africa. Access on the internet: https://pubs.acs.org/doi/pdf/10.1021/bk-20131127.ch018. 
Rural enterprise partnerships. the case of essential amathole (2015). Access on the internet: ttps://www.ecsecc.org/documentrepository/informationcentre/essentialoilsweb_91156.pdf. Valitov S.S. (2006). Konkurentne pravo Ukrainy: [navch. posibnyk]. Kyiv: Yurinkom Inter, 432.

Volkov V.P., Horoshkova L.A. (2011). Metodolohichni pidkhody do vyznachennia tendentsii dominuiuchoho konkurentnoho pozytsionuvannia na haluzevykh rynkakh. Visnyk Volynskoho instytutu ekonomiky ta menedzhmentu: zb. nauk. st. Lutsk: Volyn. in-t ekonomiky ta menedzh, Vol. 5.

Zaitseva N.O. (2011). Otsinka intensyvnosti konkurentsii u vynorobnii promyslovosti Ukrainy. Visnyk SumDU. Seriia «Ekonomika», Vol. 4.

DOI: $10.7862 /$ rz.2020.mmr.7

The text was submitted to the editorial office: March 2020.

The text was accepted for publication: March 2020. 